$1986,35,1$

\title{
INFLUENCE OF STRUCTURAL ELEMENTS ON PHYSICO-CHEMICAL PROPERTIES OF SURFACE-ACTIVE DERIVATIVES OF ALKYLAROMATIC ALCOHOLS *
}

\author{
(Presented by 0 . Kirret)
}

The sulphoderivatives of alkylaromatic alcohols synthesized by us are novel surfactants. The surface-active derivatives of alkylphenylethanols and 1-alkyl-2,4-hydroxyethylbenzene are as follows: the sodium salts of sulphoesters of secondary alkyl-2-phenyl ethanols $\mathrm{C}_{6}-\mathrm{C}_{10}$ (sulphates $\mathrm{C}_{6}-\mathrm{C}_{10}$, Table, I-V) $\left.{ }^{[1,2}\right]$, sodium salts of secondary alkyl-2-phenylethoxyethane sulphoacids (isethionates $\mathrm{C}_{6}-\mathrm{C}_{10}, \mathrm{VI}-\mathrm{X}$ ) $\left.{ }^{[3}\right]$, sodium salt of sulphoester of the secondary octyl-2-phenylethoxy-ethanol (ethoxylate $\mathrm{C}_{8}, \mathrm{XI}$ ), and sodium salts of sulphoesters of secondary 1-alkyl-2,4-hydroxyethyl benzenes (mono- and disulphate, XII, XIII) [ [4]:

$\mathrm{R}-\left(\mathrm{CH}_{2}\right)_{2} \mathrm{OSO}_{3} \mathrm{Na} \quad(\mathrm{I}-\overline{\mathrm{V}})$;

$$
\underbrace{\mathrm{OH}}_{\left(\mathrm{CH}_{2}\right)_{2} \mathrm{OH}}-\left(\mathrm{CH}_{2}\right)_{2} \mathrm{OSO}_{3} \mathrm{Na} \text { (XXI); }
$$

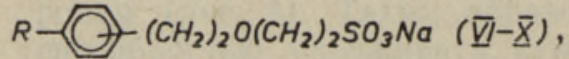<smiles></smiles>

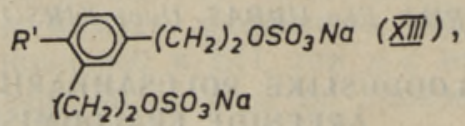

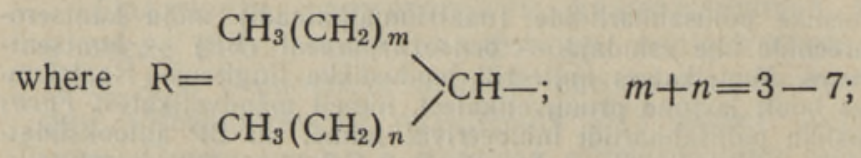

$\mathrm{R}^{\prime}=\mathrm{R}$, where $m+n=5$.

The above-mentioned compounds have been identified by sulphur and by infrared and proton magnetic resonance spectra. Every preparation is a mixture of isomers. The position of the benzene ring related to the alkyl chain has been determined already by a synthesis of alkyl benzenes which consist of a balanced mixture of isomers. According to the position of substitutes of the benzene ring, the alkylphenyl ethanols consist of orto- and para-isomers; 1-alkyl-2,4-hydroxyethyl benzene includes 1,2,4-isomer only.

The sulphates $\mathrm{C}_{6}-\mathrm{C}_{10}$, ethoxylate $\mathrm{C}_{8}$ and disulphate contain a considerable amount of sodium sulphate as a by-product. The by-product of isethionates $\mathrm{C}_{6}-\mathrm{C}_{10}$ is 1,4-disulphoethoxyethane and those of mono-

\footnotetext{
* The paper is included in the Proceedings of the World Surfactants Congress, held in München on May 6-10, 1984.
} 


\begin{tabular}{|c|c|}
\hline 咅 & 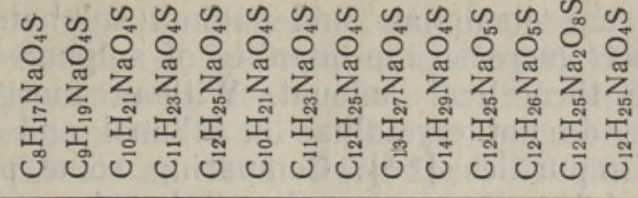 \\
\hline 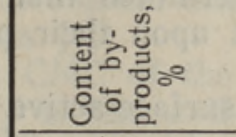 & 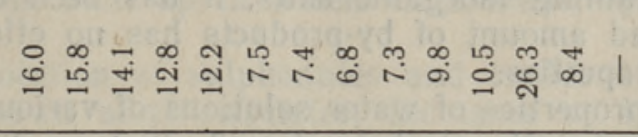 \\
\hline 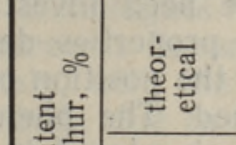 & 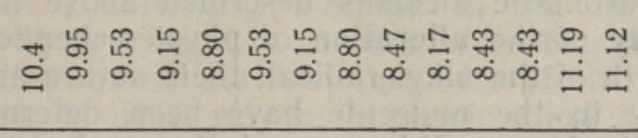 \\
\hline 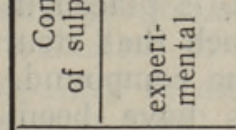 & 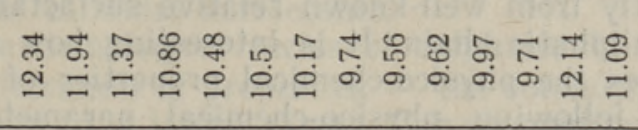 \\
\hline 彭青 & 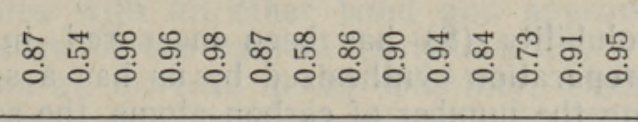 \\
\hline 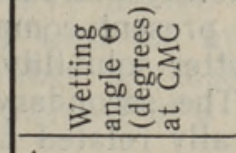 & 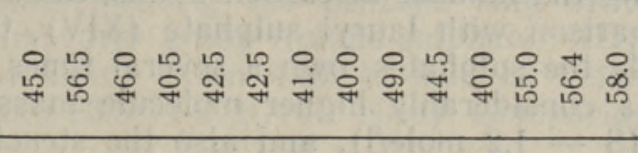 \\
\hline 茪 & 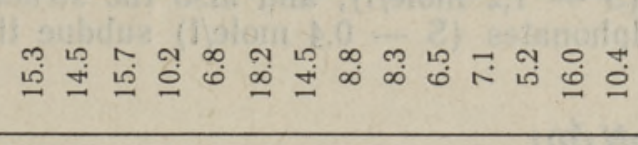 \\
\hline 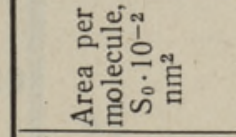 & 司 \\
\hline 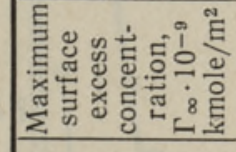 & 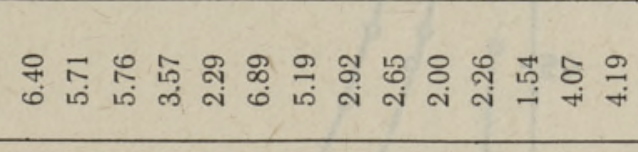 \\
\hline 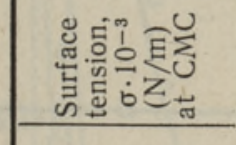 & 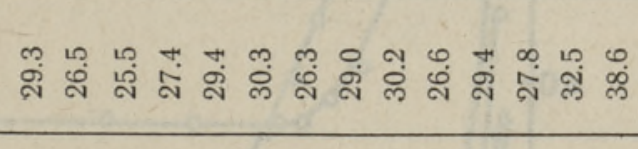 \\
\hline 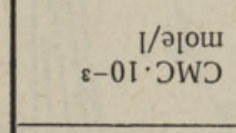 & 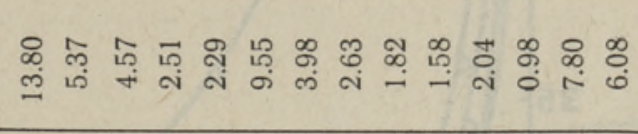 \\
\hline 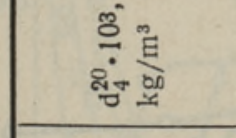 & 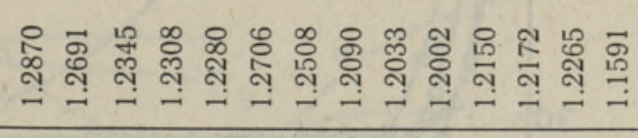 \\
\hline 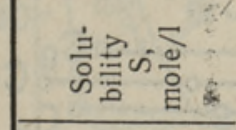 & హ్ \\
\hline$c 2$ & 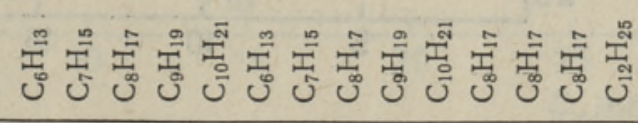 \\
\hline 乙苍諨言 & $-\exists \Xi \geq$ \\
\hline
\end{tabular}


sulphate are disulphate and sodium sulphate. All the above-mentioned by-products increase the quantity of sulphur in surfactants as compared with the theoretical amount. Without inorganic by-products the preparations do not crystallize in ethanol and are poorly separated from organic impurities $\left[{ }^{5,6}\right]$. Comparing some preparations with examples not containing inorganic salts, it has been determined that the abovementioned amount of by-products has no effect upon their physico-chemical properties.

The properties of water solutions of various surface-active derivatives of alkylaromatic alcohols described above have been investigated. The regularity of the alteration of physico-chemical properties depending on the length of the alkyl radical, their nature and the position of structural elements in the molecule have been determined. The phenylene ring, differently from well-known relative surfactants, is placed in the middle of the aliphatic chain. It is interesting how much that structural factor influences the physico-chemical properties of the compound.

The following physico-chemical parameters have been determined (Table):

1. Solubility (S) has been measured in distilled water at $20^{\circ} \mathrm{C}$. Every preparation synthesized by us has a splendid water solubility; by increasing the number of carbon atoms, the solubility decreases as usual. In comparison with lauryl sulphate (XIV), the present compounds, and especially the sulphates, own a several times better solubility even when having a considerably higher molecule mass. The secondary alkyl sulphates ( $\mathrm{S}-1,2 \mathrm{~mole} / \mathrm{l})$, and also the structurally related dodecyl benzene sulphonates $(\mathrm{S}-0.4 \mathrm{~mole} / \mathrm{l})$ subdue the present preparations [ ${ }^{7}$.

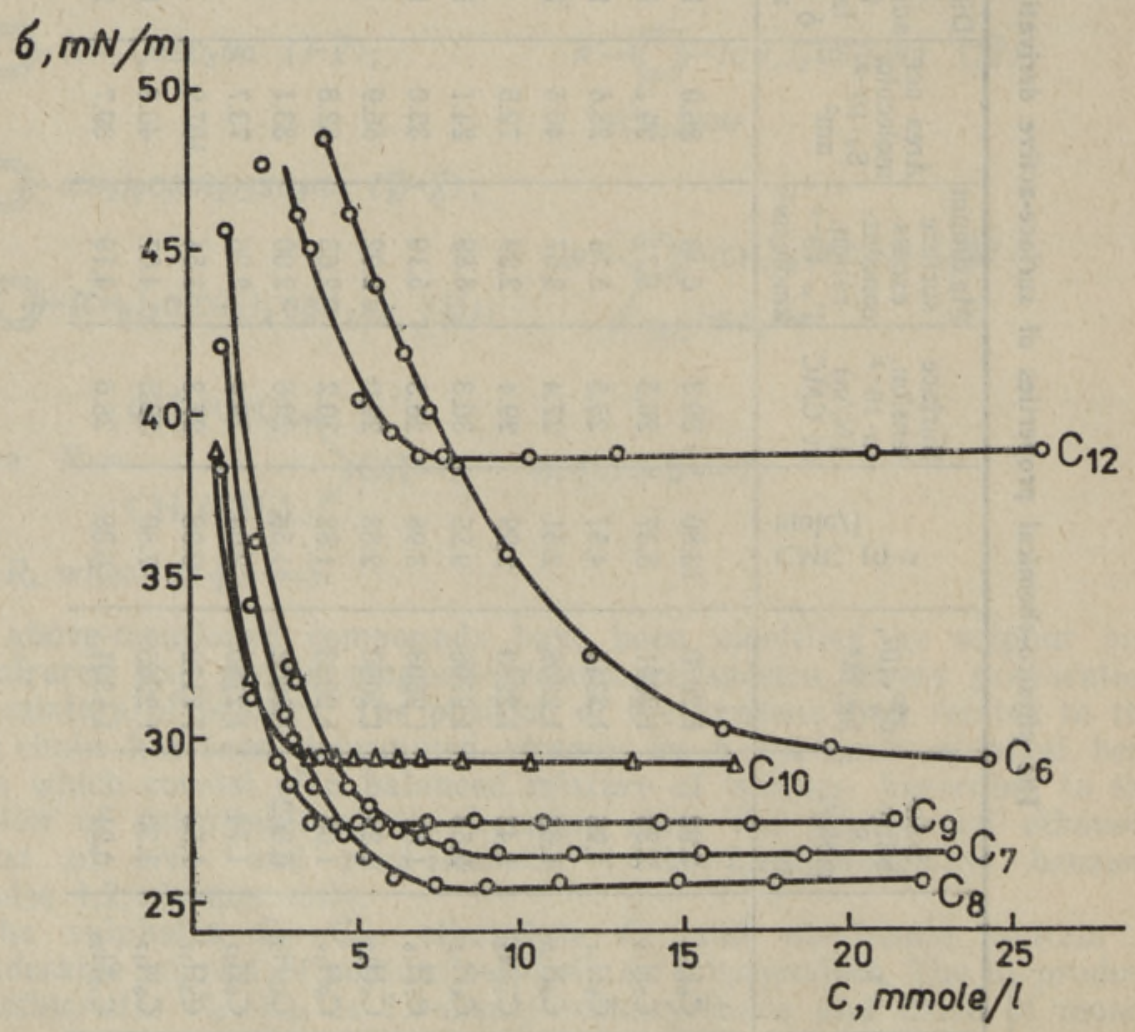

Fig. 1. Dependence of surface tension $(\sigma)$ of sulphates $C_{6}-C_{10}$ and lauryl sulphate $\left(\mathrm{C}_{12}\right)$ upon the concentration of their solutions at $20^{\circ} \mathrm{C}$.: 
2. Surface tension $(\sigma)$ and the critical micelle concentration (CMC).

In studying the properties of surfactants in relation to their structure, the more characteristic parameters are surface tension and CMC. The static surface tension has been measured by the stalagmometrical method at $20^{\circ} \mathrm{C}$ (Figs $1-3$ ). CMC has been determined by minima on the curves of surface tension, built up in a semi-logarithmic system of co-ordinates $\left[{ }^{8}\right]$.

$\sigma$ at $C M C$ of the solution of sulphonates and isethionates $C_{6}-C_{10}$; similarly to the well-known alkyl sulphates, decreases up to the intermediate homologues with a following increase in the last members. CMC decreases linearly by growing the number of carbon atoms in the alkyl chain, with the exception of the first members of the homologues series which, due to their insufficiently hydrophobic alkyl radical, have no classical properties of colloidal surfactants.

The transition of the homologues series of sulphates to isethionates is accompanied by an alteration of properties - the solubility and CMC decrease, $\sigma$ at CMC alters to a lesser extent. Complementing the hydrocarbon chain of sulphates with an ether bond and approximating the benzene ring to the centre of the radical (sulphate $\mathrm{C}_{10}, \mathrm{~V}$, and ethoxylate $\mathrm{C}_{8}, \mathrm{XI}$ ) we achieve an increase in the solubility, which rises from 1.43 to $1.74 \mathrm{~mole} / 1$. Complementing the benzene ring of the sulphate $\mathrm{C}_{8}$ (III) with the hydroxyethyl group (mono-sulphate, XII), we get a considerable decrease of CMC (from 4.57 to $0.98 \cdot 10^{-3} \mathrm{~mole} / \mathrm{l}$ ) and a certain increase of $\sigma$ (from 25.5 to $27.8 \cdot 10^{-3} \mathrm{~N} / \mathrm{m}$ ). Comparing the mono-

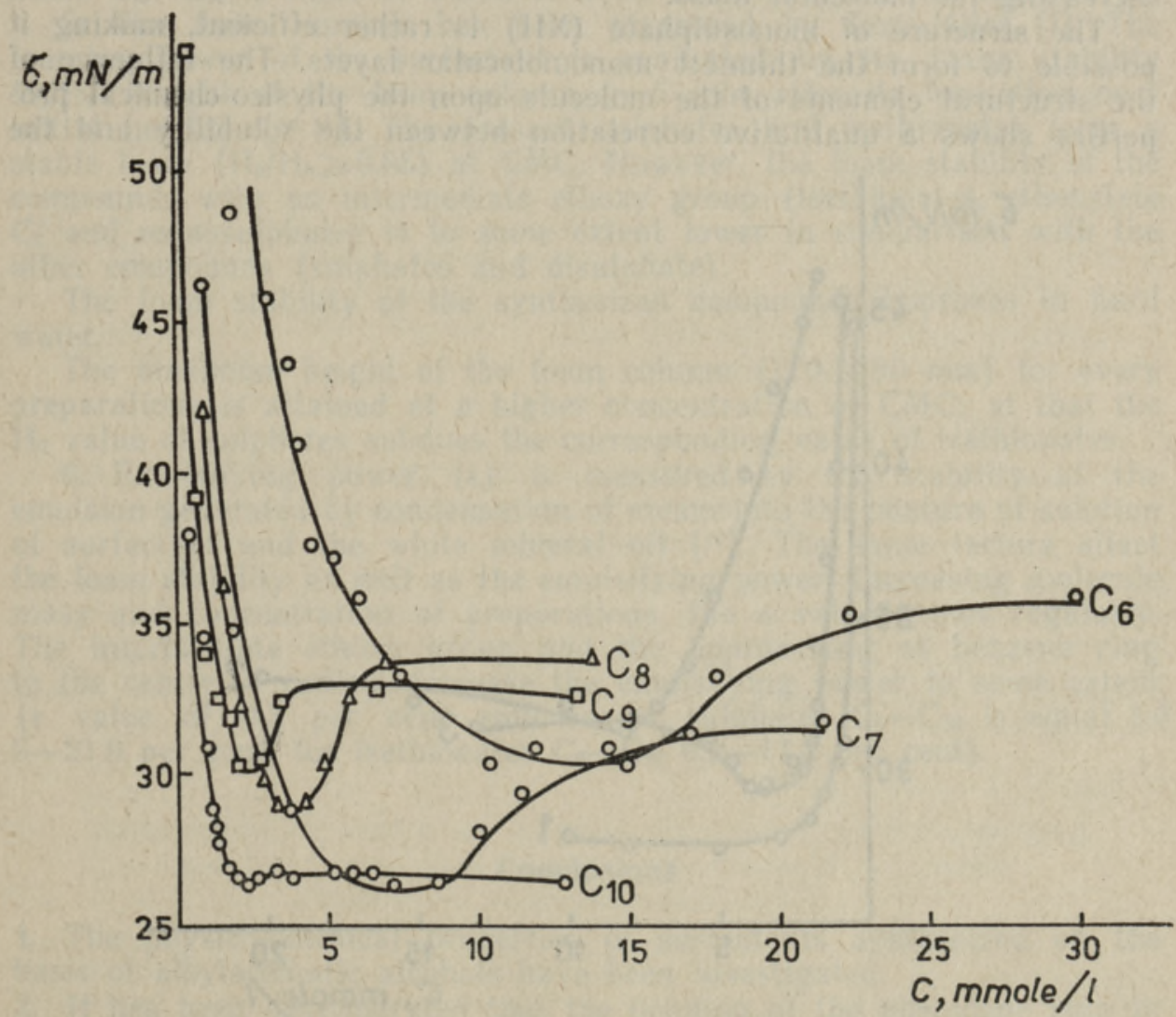

Fig. 2. Dependence of surface tension $(\sigma)$ of isethionates $C_{6}-C_{10}$ upon the concentration of their solutions at $20^{\circ} \mathrm{C}$. 
sulphate (XII) with isethionate $\mathrm{C}_{8}$ (VIII), one can see that the free alcoholic group decreases CMC more than twice, and $\sigma$ decreases from 29.0 to $27.8 \cdot 10^{-3} \mathrm{~N} / \mathrm{m}$. These alterations are explained by an increase in the dimensions of the molecule and by an improvement of the hydrophilic-lipophilic balance (HLB). Disulphate, on the contrary, has a lower surface activity, nearing by its properties to lauryl sulphate. That can be explained by the presence of two sulphate groups, resulting in a displacement of the molecule HLB in the direction of the hydrophilic part. It is remarkable that by surface activity the sulphates subdue the isethionates, which attain $\mathrm{CMC}$ at a lower concentration. Of all the experimented preparations, the best surfactant is mono-sulphate, having the least CMC at a relatively low surface tension.

3. Maximum surface excess concentration $\Gamma_{\infty}$, molecular measurements - the diameter of the adsorption layer $\delta$ and the area per molecule $S_{0}$ in the adsorption layer - have been determined by curves of the surface tension, by means of the equations of Gibbs and Langmuer $\left[{ }^{9,10}\right]$. The sufficient accuracy of the method used is confirmed by a coincidence of the experimental $\mathrm{S}_{0}$ value of lauryl sulphate $\left(39.7 \cdot 10^{-2}\right.$ $\left.\mathrm{nm}^{2}\right)$ with the values given in the relevant literature $\left(39.0\right.$ and $37.8 \cdot 10^{-2}$ $\left.\mathrm{nm}^{2}\right)\left[{ }^{11,12}\right]$.

The sharp increase in the $\mathrm{S}_{0}$ value within the range of the homologues series, by passing over from isethionate $C_{7}$ to $C_{8}$ and from sulphate $\mathrm{C}_{8}$ to $\mathrm{C}_{9}$, affirms the qualitative alteration in the structure of the surface layer. The values of $\delta$ and $\Gamma_{\infty}$ decrease as a result of the reduction of the packing density of hydrophobic radicals in the surface layer by increasing the molecular mass.

The structure of monosulphate (XII) is rather efficient, making it possible to form the thinnest monomolecular layers. The influence of the structural elements of the molecule upon the physico-chemical properties shows a qualitative correlation between the solubility and the

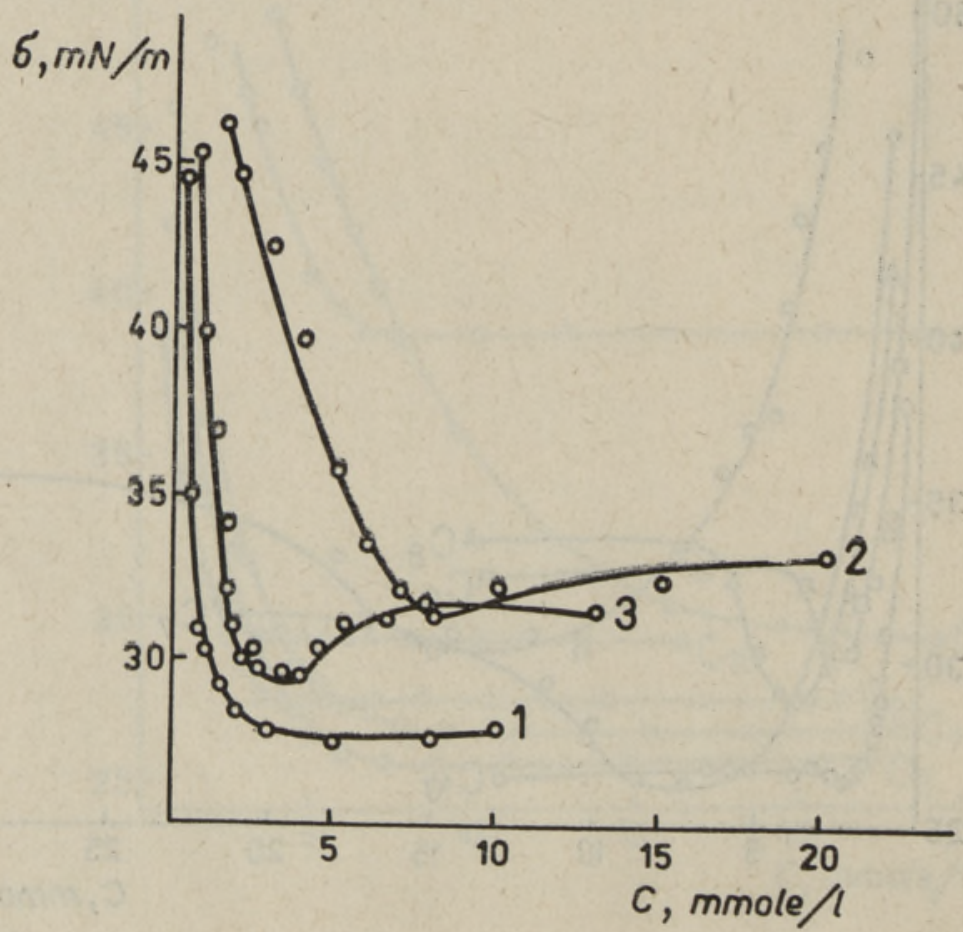

Fig. 3. Dependence of surface tension $(\sigma)$ of monosulphate $(I)$, disulphate $(2)$ and ethoxylate $\mathrm{C}_{8}(3)$ upon the concentration of their solutions at $20^{\circ} \mathrm{C}$. 
area per molecule in the adsorption layer. Substituting the sulphate group (ethoxylate $\mathrm{C}_{8}, \mathrm{XI}$ ) with sulphonate (isethionate $\mathrm{C}_{8}$, VIII), the solubility and area per molecule are subjected to the same decrease by 23.0 and 22.8 per cent, accordingly.

4. The wetting power of the solutions is estimated by the wetting angle $(A)$ which is measured in the water solution of the surfactant against paraffin at $20^{\circ} \mathrm{C}\left[{ }^{8}\right]$.

As a rule, the extreme values of the wetting power are obtained before CMC. After CMC the surface tension and the wetting angle do not change. The lowest $\theta$ value (38-46 degrees) of the sulphates is attained at the concentration that is considerably higher than CMC (from 4 to $18 \cdot 10^{-3} \mathrm{~mole} / \mathrm{l}$ ). The lowest $\theta$ value of isethionates and ethoxylate $\mathrm{C}_{8}$ can be found at $\mathrm{CMC}$ or at its significantly higher concentration. The value of the wetting angle, as well as the other properties of the surfactants, depend upon the structure of the molecule. The compounds having a phenylene ring in the middle of the alkyl chain and an intermediate ethoxy group or free hydroxyethylene group at suitable HLB, indicate a good wetting power.

For example, sulphate $\mathrm{C}_{9}$ (IV), isethionates $\mathrm{C}_{7}-\mathrm{C}_{8}$ (VII; VIII), ethoxylate $\mathrm{C}_{8}$. (XI) and monosulphate (XII) own low $\theta$ values $(38-40$ degrees), nearing $\mathrm{CMC}$ or at its relatively low concentration. The sulphate and sulphonate groups have the same wetting power, the $\theta$ values of isethionate $C_{8}$ and ethoxylate $C_{8}$ being equal (40 degrees). By their wetting power, those compounds considerably surpass the sodium lauryl sulphate, and the more relative by structure sec. alkylbenzene sulphonates $\mathrm{C}_{12}-\mathrm{C}_{18}, \theta$ value of which at $\mathrm{CMC}$ is equal to $55-60$ degrees.

5. The foam number has been measured by Ross-Miles [7]. The foaming power of the surfactant is evaluated by its foam stability $\mathrm{H}_{5} / \mathrm{H}_{0}$ (height of the foam column in $5 \mathrm{~min}$ after its formation over initial height) $\left[{ }^{13,14}\right]$. The present sulphates and isethionates form a stable foam $\left(\mathrm{H}_{5} / \mathrm{H}_{0} \geqslant 0.85\right)$ at $\mathrm{CMC}$. However, the foam stability of the compounds with an intermediate ethoxy group (isethionates, ethoxylate $\mathrm{C}_{8}$ and monosulphate) is to some extent lower in comparison with the other compounds (sulphates and disulphate). water.

The foam stability of the synthesized compounds improves in hard

The maximum height of the foam column $(170-190 \mathrm{~mm})$ for every preparations is attained at a higher concentration of $\mathrm{CMC}$; at that the $\mathrm{H}_{0}$ value of sulphates subdues the corresponding value of isethionates.

6. Emulsifying power $(\varepsilon)$ is measured by the stability of the emulsion generated by condensation of steam into the mixture of solution of surfactant and the white mineral oil [ $\left.{ }^{15}\right]$. The same factors affect the foam stability as well as the emulsifying power. Increasing molecule mass and concentration of preparations, the $\varepsilon$ value grows regularly. The intermediate ethoxy group and the approaching of benzene ring to the centre of radical decrease the emulsifying power to some extent ( $\varepsilon$ value of 0.3 per cent solution of sulphates $C_{6}-C_{10}$ is equal tol $9-21.9$ per cent, for isethionates $C_{6}-C_{10} 9.0-17.0$ per cent).

\section{Conclusions}

1. The physico-chemical properties of surfactants synthesized on the basis of alkylaromatic alcohols have been investigated.

2. It has been demonstrated that the position of the phenylene ring in the middle of the aliphatic chain increases solubility considerably, decreasing surface tension, CMC and the wetting angle of surfactant. 
3. It has been determined that the position of the phenylene ring in the middle of aliphatic chain accompanied by an intermediate ether bond or free hydroxyethyl group, decreases surface excess concentration, increasing the wetting and the foaming power.

\section{REFERENCES}

1. Ныерс Я., Урбель Х., Лахе Л. Синтез и свойства натриевых солей алкилфенилэтилсульфатов. - Изв. АН ЭССР. Хим., 1978, 27, № 2, 79-84.

2. Урбель Х., Иыерс Я. Физико-коллоидные свойства растворов алкилфенилэтилсульфатов. - Изв. АН ЭССР. Хим., 1978, 27, № 3, 157-162.

3. Урбель Х. П., Пыерс Я. Х., Файнгольд С. И. Натриевые соли алкилфенилэтилоксиэтансульфокислот как анионные поверхностно-активные вещества. Открытия. Изобретения. Промышленные образцы. Товарные знаки, 1979, № 32 , авт. свид. № 682513.

4. Урбель Х. П., Ныерс Я. Х., Файнгольд С. Н. Натриевые соли сульфоэфиров втор. алкилфенилбис (этил-2,2'-днолов) в качестве анионных поверхностноактивных веществ. - Открытия. Изобретения. Промышленные образцы. Товарные знаки, 1981, № 5, авт. свид. № 802272 .

5. Докунина E. C., Tрапезников A. A. Влияние добавок н-спиртов на кинетику понижения поверхностного натяжения растворов лаурилсульфата натрия. Коллондн. ж., 1976, XXXVIII, № 4, 675-679.

6. Hayase Kohji, Hyano Shigeo. Effect of alcohols on the critical micelle concentration decrease in the aqueous sodium dodecylsulfonate solution. - J. Colloid. and Interface Sci., 1978, 63, N 3, 446-451.

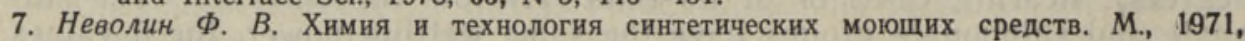
$98-104$.

8. Воюцкий C. C. Курс коллоидной химии. М., 1975, 117-121.

9. Абрамзон А. А., Бочаров В. В., Гаевой Г. М., Майофис А. Д., Майофис С. Л., Матяшкина Р. М., Сквирский Л. Я., Чистяков Б. Е., Шец Л. А. Поверхностно-активные вещества. Справочник. Л., 1979, 16-19.

10. Абрамзон A. A. Поверхностно-активные вещества. Л., 1975, 79-84.

11. Hall, D. Y., Pethica, B. A., Shinoda, K. Study of surface properties of anionic surfactants. - Bull. Chem. Soc. Jap., 1975, 48, N 1, 324-326.

12. Бреди А., Браун А. Механические свойства адсорбнрованных слоев на поверхности водных растворов мыл. М., 1956, 47-87.

13. Сквирский Л. Я. О пенообразующей способности поверхностно-активных веществ. - Коллондн. ж., 1974, XXXVI, № 3, $520-523$.

14. Пустовалов Н. Н., Пушкарёв В. В., Березок В. Г. Пенообразование в растворах алкилсульфатов натрия. - Коллондн. ж., 1974, XXXVI, № 1, 171-173.

15. Неволин $\Phi$. . В. Химня и технология синтетических моющих средств. М., 1964, $335-337$.

Academy of Sciences of the Estonian SSR, Institute of Chemistry

Received

March 25, 1985

\section{J. JOERS, Helje URBEL}

\section{- STRUKTUURIELEMENTIDE MOJUST ALKUULAROMAATSETE ALKOHOLIDE PINDAKTIIVSETE DERIVAATIDE FUUSIKALIS-KEEMILISTELE OMADUSTELE}

On uuritud sek. alküül-2-fenüületanoolide naatriumisoolade, sek. alküül-2-fenüületüüloksüetaansulfohapete naatriumisoolade ja sek. 1-alküül-2,4-hüdroksüetüülbenseenide sulfoestrite naatriumisoolade vesilahuste füüsikalis-keemiliste omaduste sõltuvust struktuurist. On määratud nende ainete lahustuvus, tihedus, pindpinevus, kriitiline mitsellimoodustamiskontsentratsioon, adsorptsioonikihi molekulaarparameetrid, märgamis-, vahumoodustamis- ja emulgeerimisvõime.

\section{Я. ИЫЕРС, Хелье УРБЕЛЬ}

\section{ВЛИЯНИЕ СТРУКТУРНЫХ ЭЛЕМЕНТОВ НА ФИЗИКО-ХИМИЧЕСКИЕ СВОИСТВА ПОВЕРХНОСТНО-АКТИВНЫХ ПРОИЗВОДНЫХ АЛКИЛАРОМАТИЧЕСКИХ СПИРТОВ}

Исследована зависимость физико-химических свойств от структуры натриевых солей сульфоэфиров втор. алкил-2-фенилэтанолов, натриевых солей втор. алкил-2-фенилэтилоксиэтансульфокислот и натриевых солей сульфоэфиров втор. 1-алкил-2,4гидроксиэтилбензолов. Установлены растворимость, плотность, поверхностное натяжение, критическая концентрация мицеллообразования, молекулярные параметры адсорбционного слоя, смачивающая, пенообразующая и эмульгирующая способности. 